\title{
The Role of Tehranian Citizens' Participation in Realization «Tobacco-Free Tehran Programme»
}

\begin{abstract}
Background and Objective: «Tobacco-Free Tehran Programme» was implemented by the Municipality of Tehran with the aim of creating a city-free by building awareness and sensitivity to the dangers of tobacco use. The researcher has analyzed the role of Tehranian citizens' participation in the realization of the "Tobacco-Free Tehran Programme».

Materials and Methods: The present has been conducted by survey method and questionnaire technique among 384 persons of citizens participating in tobacco control prevention programs in a tobacco-free week in 22 districts of Tehran municipality by convenience sampling method.

Results: Findings showed that $14.8 \%$ had complete knowledge about Tehran city without tobacco plan, $30.7 \%$ had sporadic information about this plan and $41.9 \%$ had no information about it. The results of the one-sample t-test showed that the level of citizen ss knowledge and participation in the «Tobacco-Free Tehran Programme» was low. Also, participation rate of non-smokers, women, older age groups and married people was higher than the others, but the participation of different educational and occupational groups was the same.

Conclusion: Findings implies that Tobacco-Free Tehran Programme has failed to achieve its intended objectives in the past few years in the field of tobacco control, and one of the main reasons for this has been the lack or weakness of public participation.

Keywords: Tobacco-Free Tehran Programme, Tobacco-Free, Tobacco Consumption, Participation.

Paper Type: Research Article.

Citation (Vancouver): Kharaghani K, Habibpour Gatabi K, Borandegi B. The Role of Tehranian Citizens' Participation in Realization «Tobacco-Free Tehran Programme». Iran J Health Educ Health Promot. Spring 2020;8(1): 82-92. [Persian]

Citation (APA): Kharaghani K., Habibpour Gatabi K., Borandegi B. (Spring 2020). The Role of Tehranian Citizens' Participation in Realization «Tobacco-Free Tehran Programme». Iranian Journal of Health Education \& Health Promotion., 8(1), 8292. [Persian]
\end{abstract}

Kobra Kharaghani

M.A. Student of social science search branch (Department of social science), Islamic Azad University, Tehran, Iran

Karam Habibpour Gatabi

* Assistant Professor of Department of Sociology, Kharazmi University, Tehran, Iran. (Corresponding author). karamhabibpour@yahoo.com

Badri Borandegi

Assistant Professor of Department of Sociology, Science and Research Branch, Islamic Azad University, Tehran, Iran.

Received: 15 November 2019 Accepted: 04 February 2020

Doi: 10.29252/ijhehp.8.1.5.82 


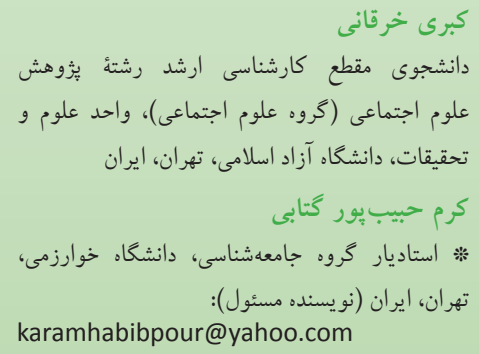

\section{4}

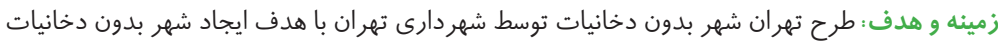

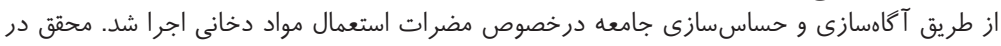

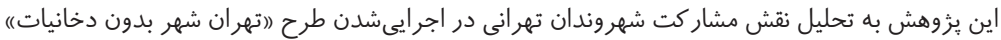
يرداخته است.

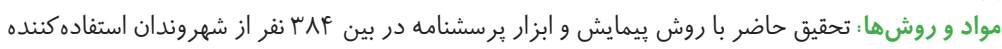

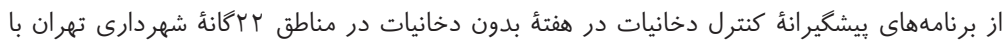

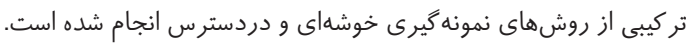

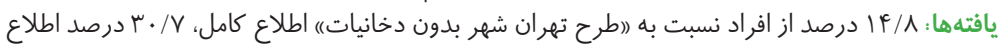

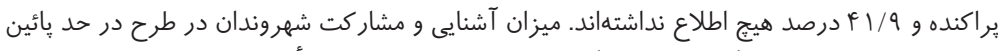

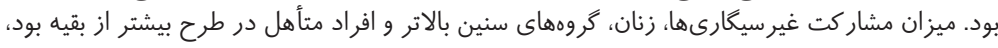

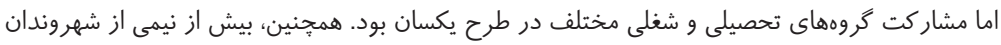

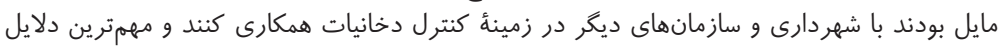

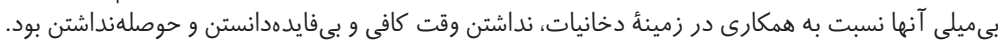

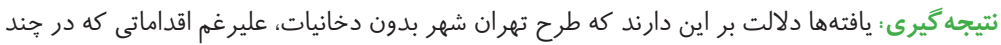

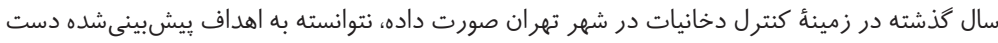

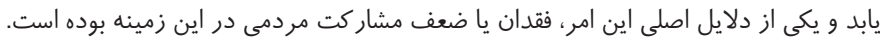

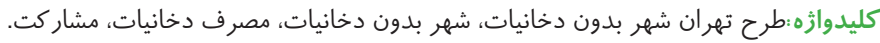

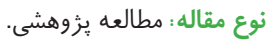

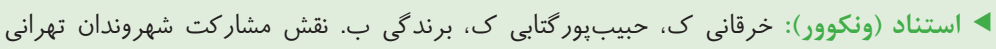

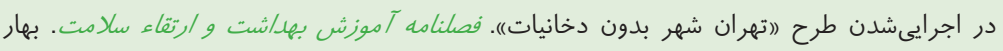
. $9 r-\Lambda r:(1) \Lambda: 1499$

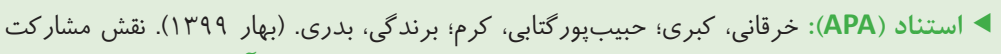

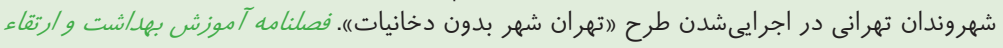


كه بين قصد ترك سيگار و قوانين مصرف سيخار در داخل خانه و

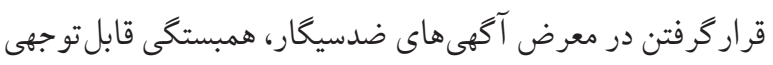

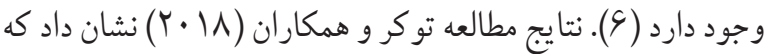
وقت اختصاصدادهشده به مشاوره بيماران در مورد سيكار كشيدن بايد شامل ارائه برخى كمكهاى مربوط به ترك باشد.(V) صرفنظر از

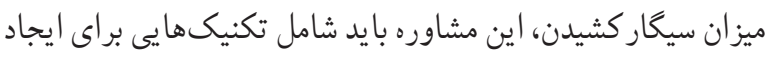
سلامتى و ايجاد انتظارات روحى اجتماعى منفى براى سيكار كشيدن باشد. اين طرحها تلاش دارند تا نشان دهند كه با بهرهكيرى از از

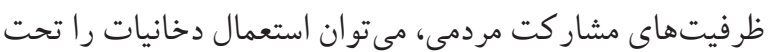
كنترل در آورد و به كاهش مصرف دخيانيات كمك نمود د. در همين مدين راستا، يكى از اقدامات مهم در كشور ايران در حوزه ييشخيرى از مصرف دخانيات، اجراى طرح ((تهران شهر بدون دخانيات)) مىباشد

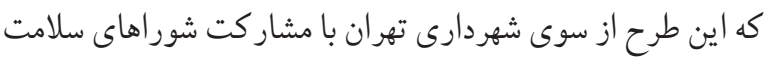

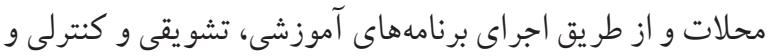
ايجاد مراكز مشاورة ترك سيكار و جلو گيرى از مصرف دخانيات

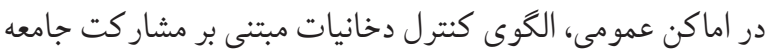
را اجرايى نموده است. نظر به اجرايىشدن اين طرح در سطح شهر

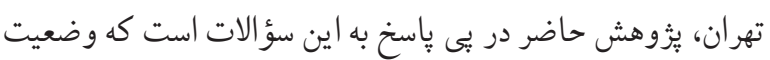

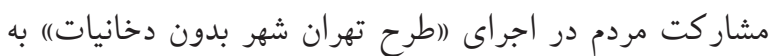

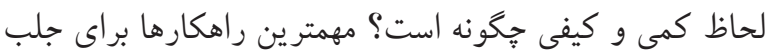
مشار كتهاى مردمى در اجراى اين طرح كداماند؟ جگگونه مى توان

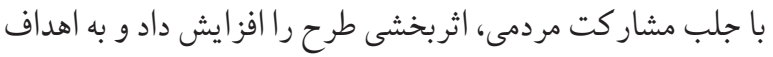

$$
\text { مورد انتظار رسيد؟ اهميت و ضرورت مت تحقيت }
$$

اهميت و ضرورت بررسى موضوع تحقيق از جندين جنبه قابل بررسى است. جنبه اول به افزايش روبهتزايد مصرف سيخار در بين

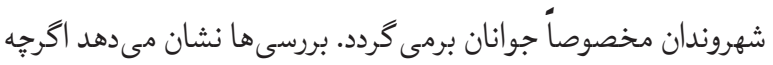
در سالهاى اخير برنامههاى بهداشتى در برخى كشورهاى توسعه يافته

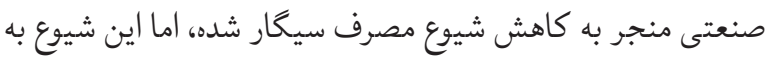
ويثه در سنين پايين در كشورهاى درحال توسعه و يا كمدرآمد در
مصرف دخانيات يكى از مهمترين عوامل تهديدكنندة سلامتى و شايع ترين عامل قابل بيشگيرى مرگ مرمير در جهان است. درحالحاضر ه ميليون نفر در جهان به علت ابتلا به بيمارى هاى ناشى از استعمال دخانيات مى ميرند كه بيشبينى مىشود تا سال • ·ץ و شايد هم زودتر، اين نسبت به يك نفر در هر شش نفر يعنى •ا ميليون مرك در سال برسد( (l). مصرف سالانه سيگار در ايران بر اساس متوسط بر آوردهاى برداي مر اجع آمارى كشور برابر با همهيليارد نخ سيخار است كه ساليانه حدود • إهزار ميليارد تومان صرف دود كردن سيكار مىشود(ب)

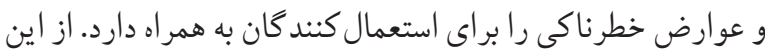

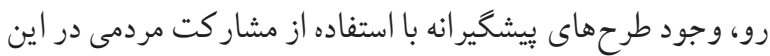
زمينه از ضرورت دو קندانى برخوردار مى باشد و سياست گذاران در اين حوزه بايد به نقش عامل مشار كت مردمى توجه نمايند. استفاده

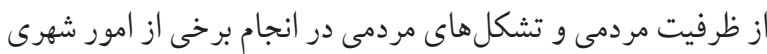
يكى از موضوعات مهم و قابلتوصيه در اين زمينه است(ب) به مرديه كونهاى كه ركن اصلى اجراى بروزةهاى توسعه شهرى مشاركت همه جانبه يخانهاى سازنده جامعه شهرى (افر اد و گروهاى شهرى)

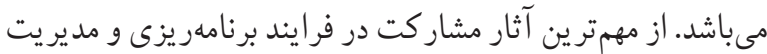

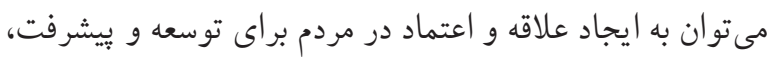
تقويت همبستكى اجتماعى و روحيه همكارى و همدلى، استفاده بهينه از منابع و امكانات عمومى و خصوصى و كاهش تمركز كرايى

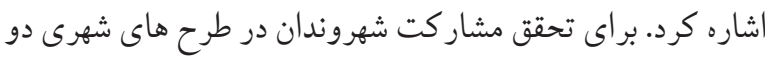
بيششرط ضرورى است: 1 - گرايش و تمايلات و انكيزه مشار كت.

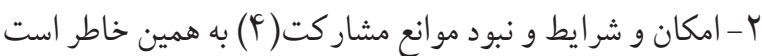

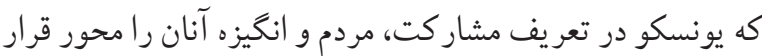
مىدهد و مشاركت را حق بشر و بيششرط توسعه مىداند و معتقد

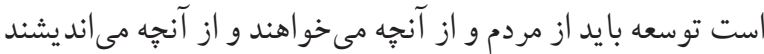
و باور دارند آغاز شود(ه). (ه).

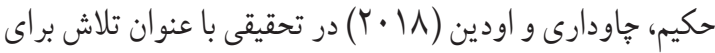

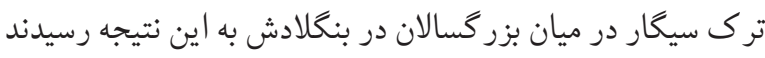


شدند. در كام دوم، بهمنظور دسترسى به افراد نمونه، در درون هر

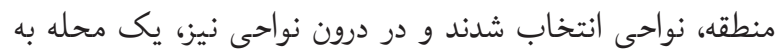

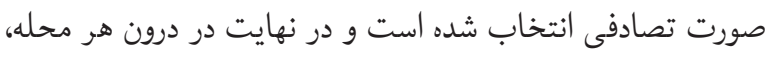
يك بلوك به صورت تصادفى انتخاب شده است. در كام آخر، به منظور رسيدن به نمونهها از روش نمونه كيرى دردسترس استفاده

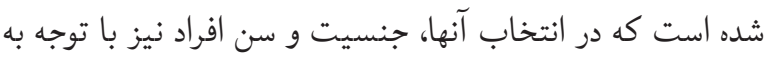
ميزان حضور و استفادة أنها از برنامه ها لحاظ شده است. حجم نمئ نمونه تحقيق براساس فرمول كوكران بين مناطق ذكرشده، انتخاب شدهاند.

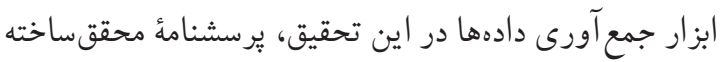

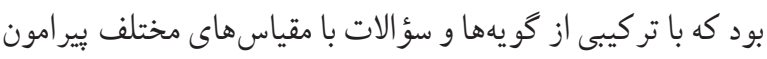

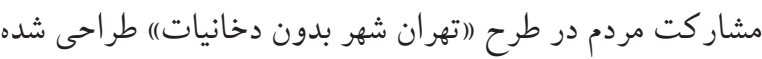
بود. در اين تحقيق، مشاركت مردم در اجراى طرح (اتهران شهر

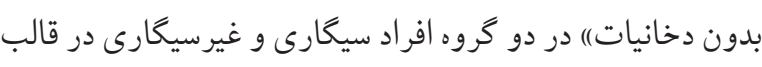
معرفهاى مشابه و متفاوت سنجش شده است (جدول (1).

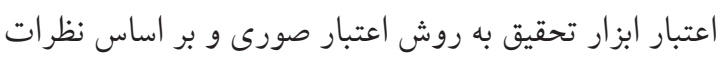

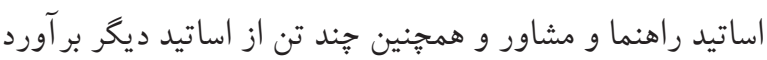

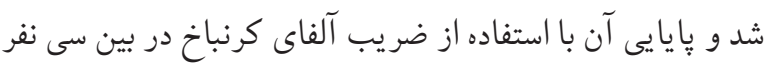

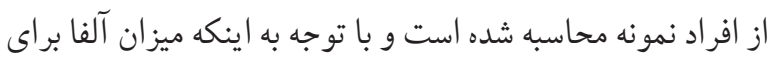
شاخصهاى تحقيق بيشتر از V, • بود، پايا بودن ابزار تحقيق تأييد شد.

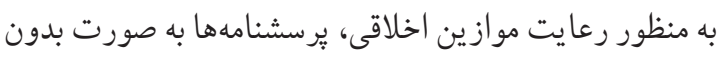

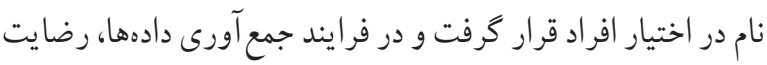

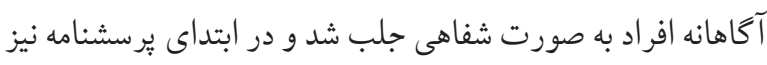
اين مورد به افراد به صورت كتبى توضيح داده شد.

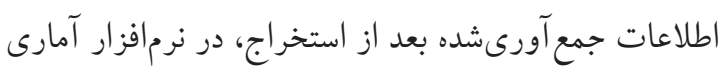
SPSS

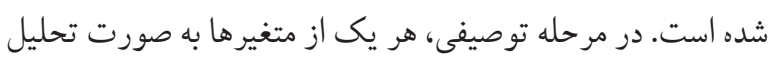

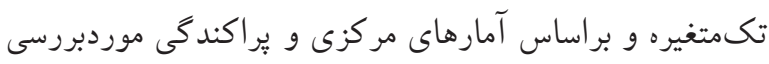

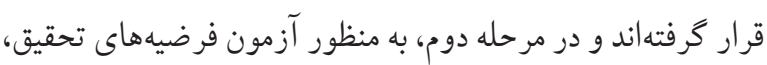

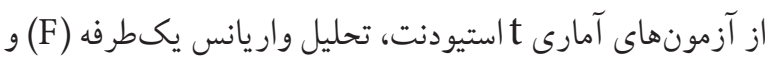

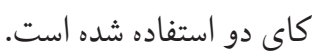

حال افزايش است. مطالعات اخير نشان مىدهد جه در كشورهاى توسعه يافته و جه در كشورهاى درحال توسعه، شيوع مصرف سيخار

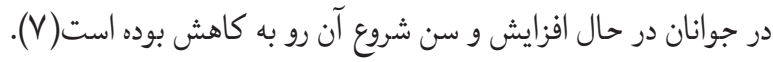
اين مسايل لزوم توجه هرجه بيشتر به طرحهاى پيشخيرانه مانند

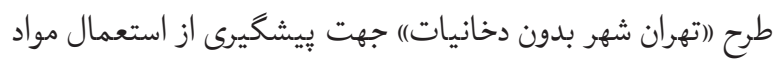
دخانى در كشور و فراهم كردن زمينه براى مشاركت شهروندان جهت اثربخشى حداكثرى جنين طرح هايى را نمايانتر ساخته است. از سويى ديخر تحقيق حاضر مى تواند شناختى از وضعيت موجود

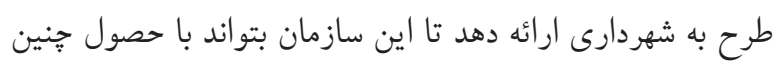

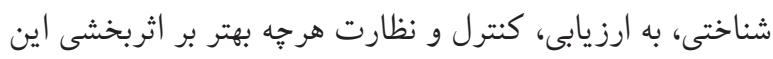

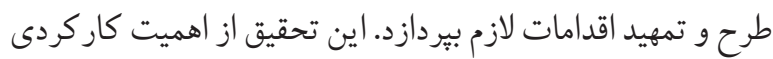

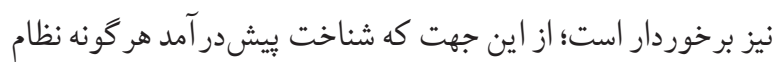
سياست گذارى و برنامهريزى است. تحقيق حاضر مى تواند موانع،

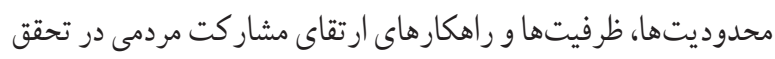
طرح (تهران شهر بدون دخانيات)) را مشخص نمايد و تصويرى از آنها به مسؤلين جهت اتخاذ سياستها و برنامهاى عملياتى لازم ارائه دهد. روش ״ُوهش حاضر از حيث روش، در زمره تحقيقات كمى مى باشد كه به صورت بيمايش انجام شده است و به لحاظ هدف، جزء تحقيقات

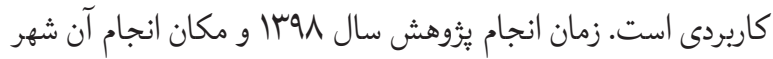
تهران بود. جامعه آمارى اين تحقيق شامل شهروندان استفاده كننده از برنامههاى بيشخيرانه كنترل دخانيات در هفته بدون دخانيات

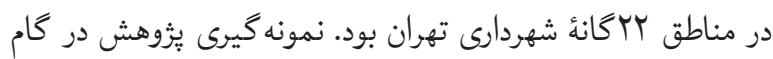

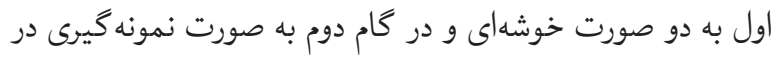
دسترس مىباشد. بر اين اساس، خوشه اول، مناطق مختلف شهر تهران بود كه براساس سطح توسعه يافتكى آنها دستهبندى شدند. در اين مرحله، ينج منطقه شامل منطقه ب (منطقة توسعه يافته)،

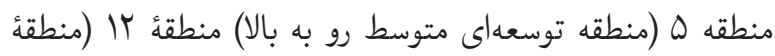
توسعهاى متوسط)، منطقه 10 (منطقه توسعهاى متوسط رو به يايين) و منطقة 19 (منطقة توسعهنيافته) به عنوان قلمرو مطالعه انتخاب 
جدول ا. معرفهاى مشاركت مردم در اجراى طرح (تهران شهر بدون دخانيات) به تفكيك افراد سيكارى و غيرسيخارى

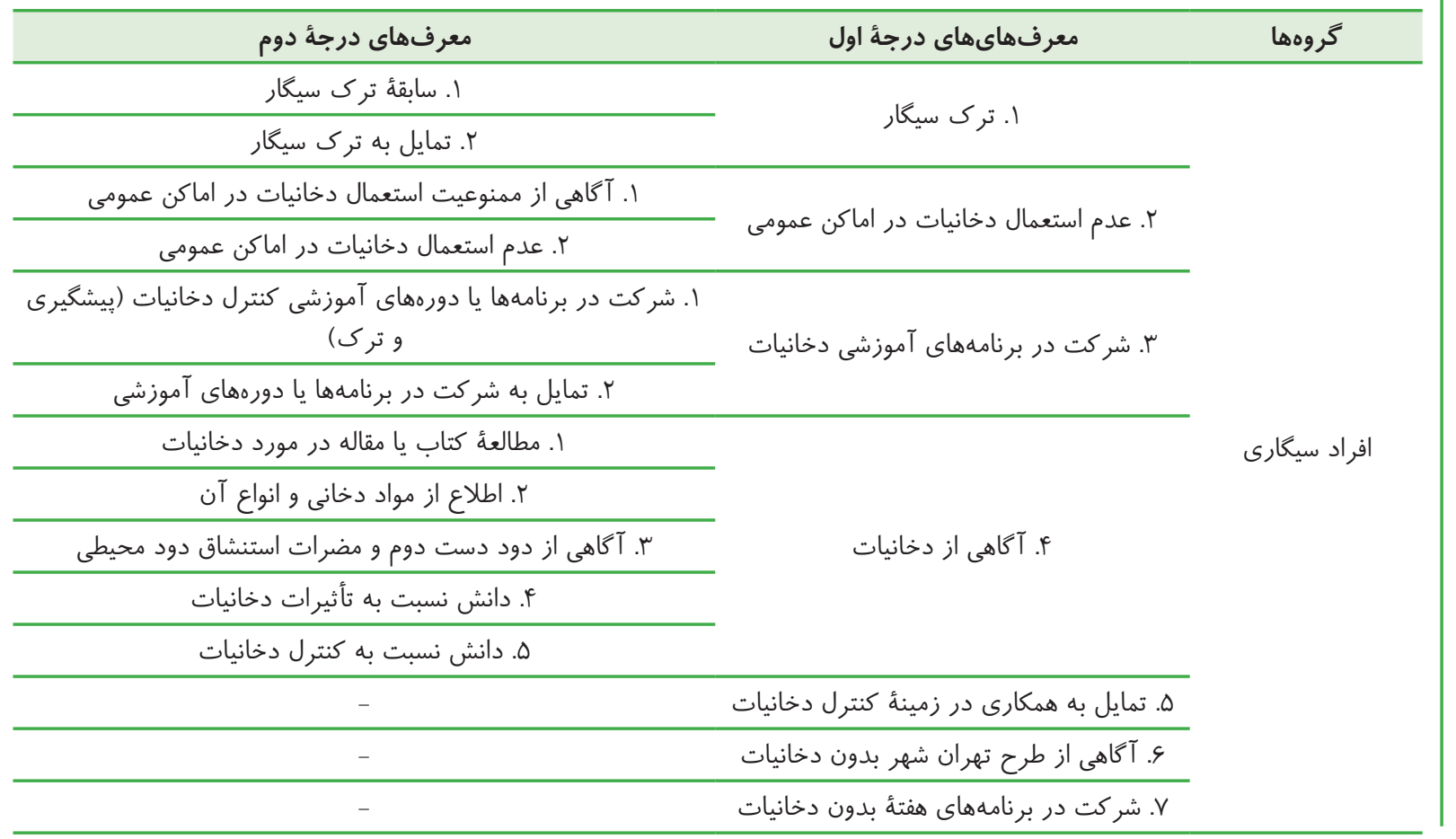

ا. ا. توصيه به ديكران نسبت به عدم استعمال دخانيات

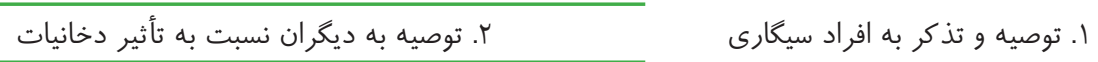

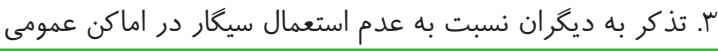

r. ( تشويق ديكران به عضويت در كانون پاد

1. مطالعُّ كتاب يا مقاله در مورد دخانيات

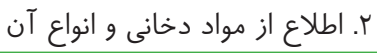

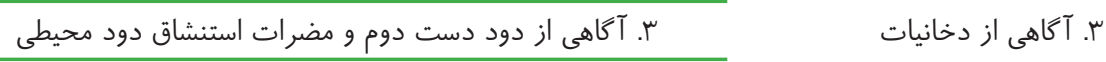

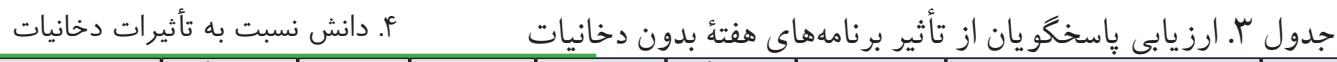

\begin{tabular}{|c|c|c|c|c|c|c|c|c|c|c|c|}
\hline SD & $\mathbf{M}$ & كل & بى جواب & كخالفال & مخالفم & بينابين & موافقم & كماملاً & شاخص & كو يهها & رديف \\
\hline \multirow[b]{2}{*}{$1 / \Delta V$} & \multirow[b]{2}{*}{$r / 9$} & rat & kr & lky & $1 \ldots$ & V) & YY & $r$ & فرلولولن & \multirow{2}{*}{ راجع به شده كه اطلاعاتم } & \multirow[b]{2}{*}{1} \\
\hline & & $1 \ldots$ & $1 . / 9$ & $\Gamma \vee / \Delta$ & Tq & $1 N / \Delta$ & $9 / \pi$ & $\cdot / 1$ & درصد & & \\
\hline
\end{tabular}

ا. سابقة شركت در برنامهها يا دورههاى آموزشى كنترل دخانيات

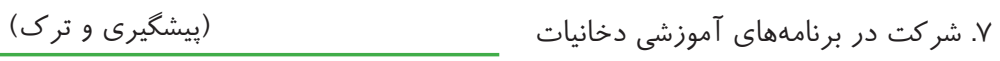

r. ا. تمايل به شر كت در برنامهها يا دور وهاى آموزشى دخانيات

1. 1. تمايل به همكارى در زمينة كنترل دخانيات

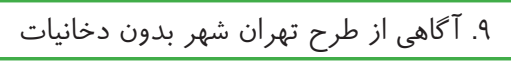

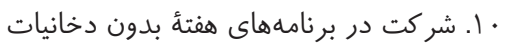




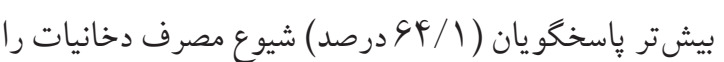

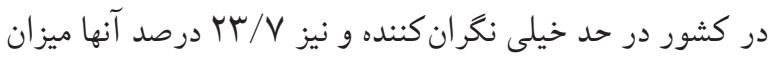

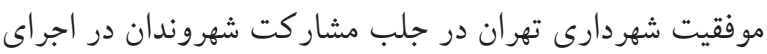

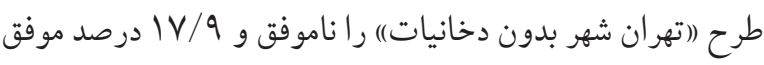

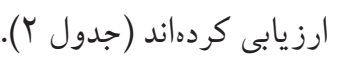

FN/T. درصد ياسخكويان زن و FV/9. درصد مرد بودند كه ميانگين

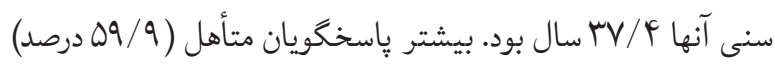

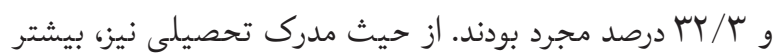

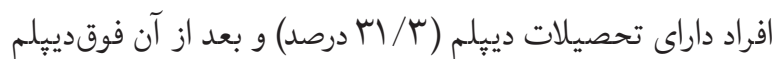
و ليسانس (V/ •r درصد) و V/ I/ درصد نيز داراى تحصيلات

جدول ז. توزيع ياسخكَويان برحسب ارزيابى آنها از موفقيت شهردارى در جلب مشاركت شهروندان جهت كنترل دخانيات

\begin{tabular}{|c|c|c|}
\hline \multicolumn{2}{|c|}{ شهروندان } & \multirow[t]{2}{*}{ كويه } \\
\hline درصد & فراوانى & \\
\hline$f / f$ & IV & خيلىزياد \\
\hline $1 \pi / 0$ & $\Delta r$ & زياد \\
\hline$r \Delta / v$ & Irv & تاحدى \\
\hline $1 r / r$ & iv & كم \\
\hline $11 / 0$ & Fq & خيلى كم \\
\hline$s / \mu$ & re & اصلاً \\
\hline $9 / 1$ & ro & نمى دانم \\
\hline $\mathrm{V} / \mathrm{r}$ & rᄉ & بىجواب \\
\hline $1 \ldots$ & rAr & جمع كل \\
\hline
\end{tabular}

دادههاى يُزوهش بود. بر همين اساس، به منظور آزمون فرضيات

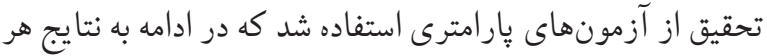
يك از آزمون فرضيهها اشاره مىشود: فرضيه اول: "ميزان مشاركت شهروندان در طرح تهران بدون دخانيات در حد پائين است

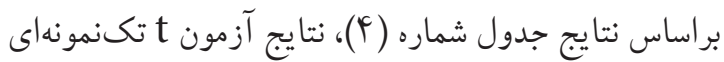

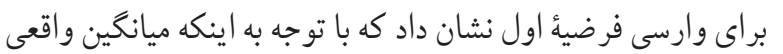

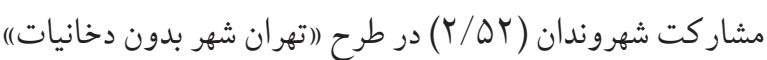

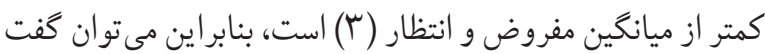
كه ميزان مشاركت شهروندان در طرح در حد پِ يين است و بنابراين

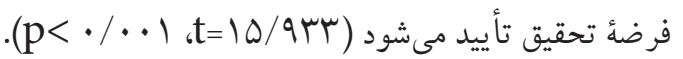

IV/9 درصد شهروندان معتقد بو دند شهردارى در جلب مشار كت شهروندان جهت كنترل دخانيات در حد زياد و خيلىزيادى موفق

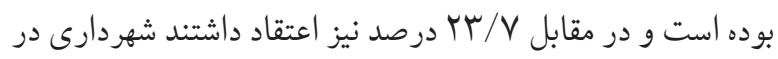
اين رابطه در حد كم و خيلى كمى موفق بوده است. ب/ 9 درصد نيز معتقد بودند كه شهردارى در اين خصوص اصلاً موفق نبوده است.

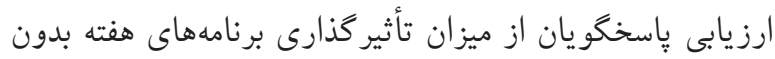

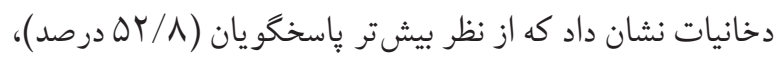

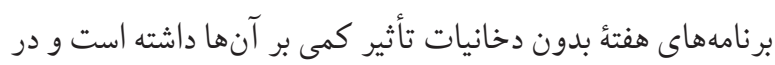

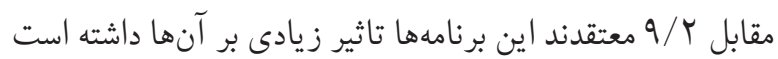

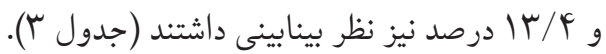

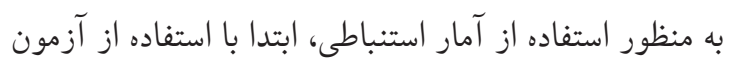

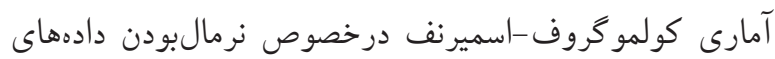
يزوهش قضاوت شد كه نتيجه اين آزمون نشاندهنده نرمال بودن 
جدول س. ارزيابى پاسخعَويان از تأثير برنامههاى هفتَّ بدون دخانيات

\begin{tabular}{|c|c|c|c|c|c|c|c|c|c|c|c|}
\hline SD & M & كل & بى جواب & 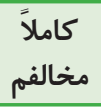 & مخالفم & بينابين & موافقم & موافلاً & شاخص & كويلها & رديف \\
\hline \multirow{2}{*}{$1 / \Delta V$} & \multirow{2}{*}{$r / s$} & rᄉF & fr & IFF & $1 \cdots$ & VI & rF & r & فراوانى & \multirow{2}{*}{ باعث شده كه اطلاعاتم راجع به مواد } & \multirow{2}{*}{1} \\
\hline & & $1 \cdots$ & $1 \cdot / 9$ & $r V / \Delta$ & rs & $1 N / 0$ & $s / r$ & $\cdot / 1$ & درصد & & \\
\hline \multirow{2}{*}{$1 / 09$} & \multirow{2}{*}{ r/ט } & rNA & pr & Irv & $1 \cdot 1$ & $9 \Lambda$ & I & f & فراوانى & \multirow{2}{*}{ مضرات شده كواد دخانى بيشتر شاتم راجع به. } & \multirow{2}{*}{$r$} \\
\hline & & $1 \cdots$ & $11 / r$ & $r \Delta / v$ & $r \varphi / r$ & $I V / V$ & $1 / 1$ & 1 & درصد & & \\
\hline \multirow[b]{2}{*}{$1 / 9 r$} & \multirow[b]{2}{*}{$r / \mathcal{e V}$} & rᄉr & FV & IrT & $1 \cdot r$ & $S V$ & r & 0 & فراوانى & \multirow{2}{*}{ به برث شده دخه از اين به بعد، نسبت به دهران } & \multirow[b]{2}{*}{ r } \\
\hline & & $1 \ldots$ & $1 r / r$ & $\mu F / \mathcal{F}$ & $r G / G$ & $I V / F$ & $1 / 1$ & $1 / \mu$ & درصد & & \\
\hline \multirow[b]{2}{*}{$1 / G F$} & \multirow[b]{2}{*}{$\boldsymbol{m} / \boldsymbol{F} \wedge$} & rNe & $\uparrow \wedge$ & Ir人 & 90 & $S V$ & r & 0 & فراوانى & \multirow{2}{*}{ 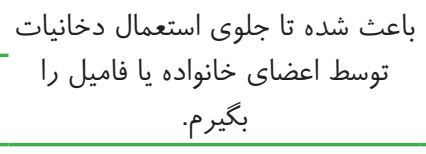 } & \multirow[b]{2}{*}{ r } \\
\hline & & $1 \cdots$ & $r \Delta / q$ & $Y F / V$ & $I V / F$ & $\Lambda / /$ & $1 / \mu$ & $1 r / 0$ & درصد & & \\
\hline \multirow[b]{2}{*}{$1 / G F$} & \multirow[b]{2}{*}{$r / \Delta r$} & rNA & is & 140 & $1 \cdots$ & $\Delta r$ & rs & $\Delta$ & فر اوانى & \multirow{2}{*}{ باعث شده تا مضرات استنشاق دود دور افران } & \multirow[b]{2}{*}{$\Delta$} \\
\hline & & $1 \cdots$ & Ir & rV/A & TS & $1 \pi / 0$ & $q / F$ & $1 / \mu$ & درصد & & \\
\hline \multirow[b]{2}{*}{$r / \cdot r$} & \multirow[b]{2}{*}{$1 / \mu^{\mu} \wedge$} & rᄉr & ror & st & I & $r r$ & ir & r & فر اوانى & \multirow{2}{*}{ 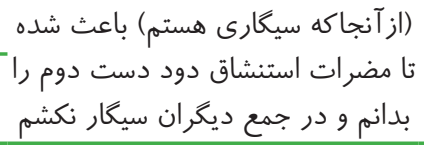 } & \multirow[b]{2}{*}{4} \\
\hline & & $1 \cdots$ & $S D / S$ & $19 / 4$ & $\Lambda / 1$ & $\Delta / V$ & $r / 1$ & 1 & درصد & & \\
\hline \multirow{2}{*}{$1 / 4$} & \multirow{2}{*}{ r/ls } & rNF & $\wedge$. & IrV & $\wedge \Lambda$ & $\Delta \Lambda$ & rV & f & فر اوانى & \multirow{2}{*}{ شاخص كل } & \\
\hline & & $1 \cdots$ & $r F / G K$ & $\mu \mathrm{r} / \wedge$ & $r I / V$ & $1 \pi / 4$ & $s / \cdot 0$ & $r / l F$ & درصد & & \\
\hline
\end{tabular}

جدول عا. نتايج آزمون t تكنمونهاى به منظور بررسى مشاركت شهروندان در طرح تهران بدون دخانيات

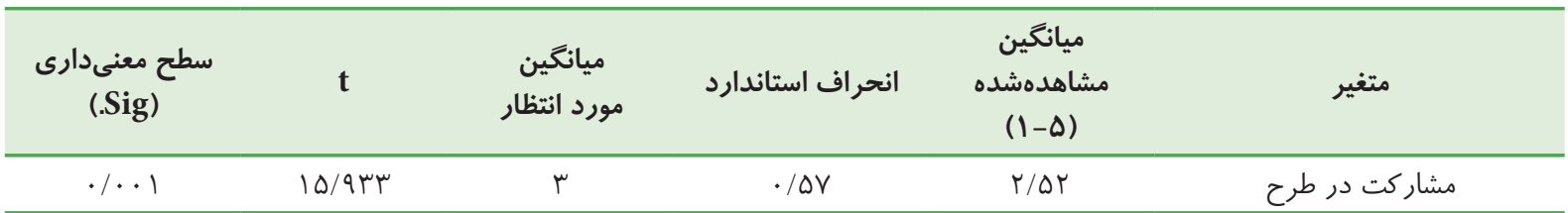

فرضيه دوم: "ميزان مشاركت شهروندان سيكارى و غيرسيكارى در (تهران شهر بدون دخانيات)) متفاوت است و بنابراين فرضهُ تحقيق

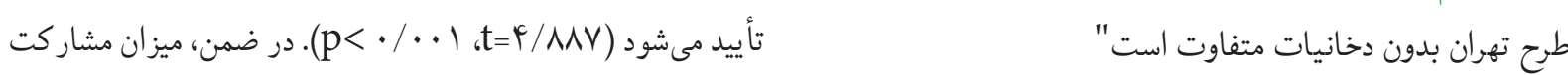

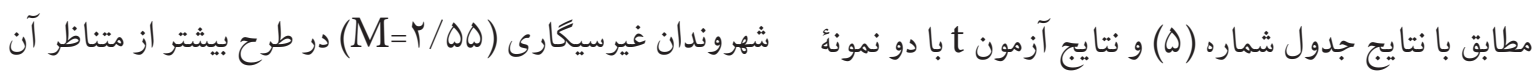

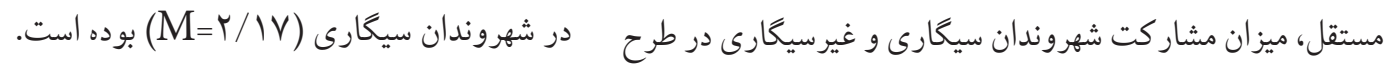

جدول ه. نتايج آزمون t با دو نمونه مستقل به منظور مقايسه مشاركت شهروندان سيگارى و غير سيعارى در طرح تهران بدون دخانيات

\begin{tabular}{|c|c|c|c|c|c|}
\hline $\begin{array}{c}\text { سطح معنىدارى } \\
\text { (Sig) }\end{array}$ & $\mathbf{t}$ & انحراف استاندارد & ميانكين & كروه & متغير \\
\hline \multirow{2}{*}{.$/ \cdot 1$} & \multirow{2}{*}{$F / \Lambda \wedge V$} & $\cdot / \Delta r$ & $r / I V$ & سيغارى & \multirow{2}{*}{ مشاركت در طرح } \\
\hline & & .100 & $r / \Delta \Delta$ & غير سيخارى & \\
\hline
\end{tabular}




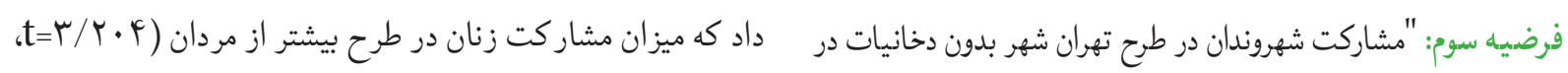

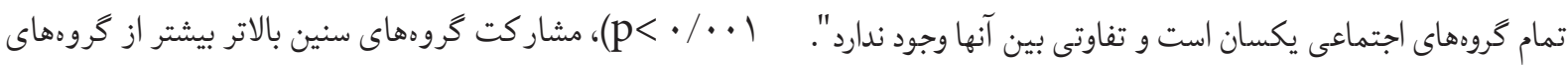

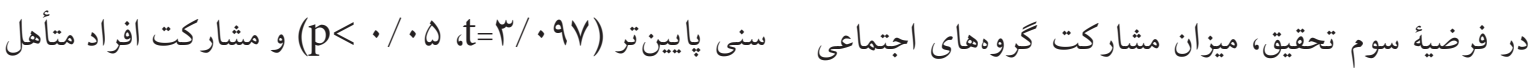

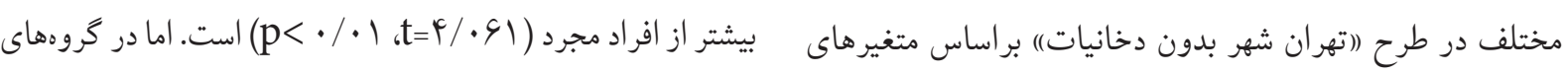

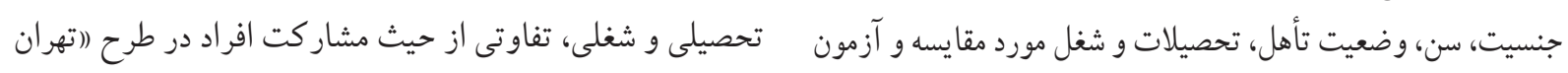

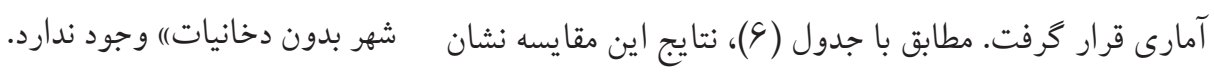

جدول و. مقايسه ميزان مشاركت شهروندان در طرح تهران بدون دخانيات برحسب متغيرهاى زمينهاى

\begin{tabular}{|c|c|c|c|c|c|c|}
\hline $\begin{array}{c}\text { سطح معنىدارى } \\
\text { (Sig) }\end{array}$ & $\mathbf{t} / \mathbf{F}$ & انحراف استاندارد & ميانكين & كروه & مستقل & متغير وابسته \\
\hline \multirow[t]{2}{*}{$\cdot 1 \cdot \cdot 1$} & \multirow{2}{*}{$-r / r \cdot r$} & $\cdot / \Delta S$ & $r / F r$ & مرد & \multirow{2}{*}{ جنس } & \multirow{17}{*}{$\frac{3}{3}$} \\
\hline & & $\cdot / \Delta \Lambda$ & $r / s \mid$ & زن & & \\
\hline \multirow{5}{*}{.$/ .19$} & \multirow{5}{*}{$r / .9 V$} & $\cdot / \mathcal{F V}$ & $r /$ re & ه سال و پايينتر & \multirow{5}{*}{ سن } & \\
\hline & & $\cdot / 0$ & $r / \Delta r$ & צr تا هץ سال & & \\
\hline & & $\cdot / \Delta \Lambda$ & $r / \Delta r$ & צr تا هـ سال & & \\
\hline & & $\cdot / 9 \Lambda$ & $r / \Delta S$ & צ\& تا ها سال & & \\
\hline & & $\cdot / 9 r$ & $r / Y^{F}$ & هه سال و بالاتر & & \\
\hline \multirow{4}{*}{$\cdot / \cdots v$} & \multirow{4}{*}{$r / .41$} & $\cdot / 09$ & $r / r$ & مجرد & \multirow{4}{*}{ وضعيت تأهل } & \\
\hline & & $\cdot 100$ & $r / \Delta \varphi$ & متأهل & & \\
\hline & &.$/ 9 r$ & $r / 99$ & مطلقه / متار كه & & \\
\hline & & $\cdot / 9 r$ & $r / F \wedge$ & همسر فوت كرده & & \\
\hline \multirow{4}{*}{$\cdot / \cdot \wedge \Delta$} & \multirow{4}{*}{ r/Trt } & $\cdot / \Delta \vee \wedge$ & $r / G Y$ & راهنمايى و پايينتر & \multirow{4}{*}{ تحصيلات } & \\
\hline & & $\cdot / \Delta \Delta$ & $r / \Delta r$ & دييلم & & \\
\hline & & $\cdot / \Delta V$ & $r / F r$ & فوقدييلم و ليسانس & & \\
\hline & & $\cdot / \Delta \mu$ & $r / G r$ & فوقليسانس و بالاتر & & \\
\hline \multirow{2}{*}{ - /MNY } & \multirow{2}{*}{.$/ 14 q$} & $\cdot / \Delta V$ & $r / \Delta r$ & شاغل & \multirow{2}{*}{ 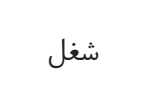 } & \\
\hline & & $\cdot / \Delta \Delta$ & $r / \Delta 1$ & غيرشاغل & & \\
\hline
\end{tabular}

دخانيات) اطلاعى نداشته و در مقابل تنها DV نفر اطلاع كامل از طرح

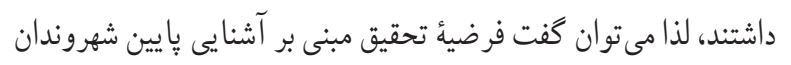

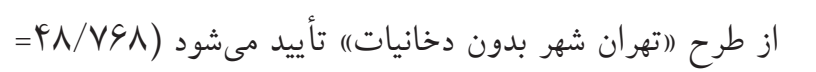
$\cdot\left(\mathrm{p}<\cdot / \cdot \Delta \cdot \chi^{2}\right.$
فرضيه جهارم: (اميزان آشنايى شهروندان از طرح تهران بدون دخانيات در حد يائين مىباشد). نتايج جدول (V) و آزمون كاى دو نشان داد كه تفاوت بين توزيع

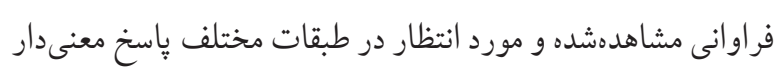
است و با توجه به اينكه اع| نفر از شهروندان از طرح (اتهران شهر بدون 
جدول V. آزمون كاى دو تك نمونه براى بررسى آشنايى شهروندان از طرح تهران بدون دخانيات

\begin{tabular}{|c|c|c|c|c|}
\hline $\begin{array}{c}\text { سطح معنىدارى (Sig) } \\
\text { (Sig) }\end{array}$ & $\chi r$ & فراوانى مورد انتظار & فراوانى مشاهده شده & متغير \\
\hline \multirow{3}{*}{$\cdot / \cdot \cdot 1$} & \multirow{3}{*}{$\nvdash \wedge / \vee \subseteq \wedge$} & $11 r$ & $\Delta V$ & بله كاملاً اطلاع دارم \\
\hline & & $11 r$ & 111 & بله يراكنده اطلاع دارم \\
\hline & & $11 r$ & 191 & خير اطلاعى ندارم \\
\hline
\end{tabular}

بحث و نتيجه كيرى

افزايش آكاهى جامعهُ هدف ضرورى است تا بتوان در مرحلهُ بعد، انتظار مشار كت جدى تر آنها در طرح را داشت. طبق مدل اعتقاد بهداشتى، در گام اول و به منظور افزايش مشاركت افر اد در طرحهاى مشابه طرح تهران شهر بدون دخانيات، بايستى درك افر اد از موضوع طرح، در سطح قابلقبولى باشد. وقتى وضعيت موجود به عنوان نوعى تهديد براى سلامتى و... براى افراد تلقى شود، آنها به دركى دوري صحيح از ريسكهاى وضعيت موجود رسيده و مىتوانند شدت ريسك يذيرى آن وضعيت را بر آورد نمايند و براساس نتيجة اين

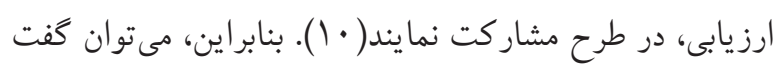

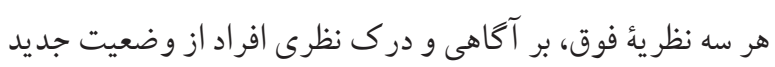

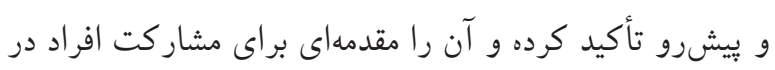
نظر مى كيرند.

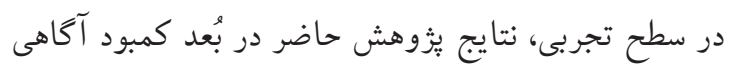
جامعهُ هدف از طرح ((تهران شهر بدون دخانيات)) با نتايج تحقيق

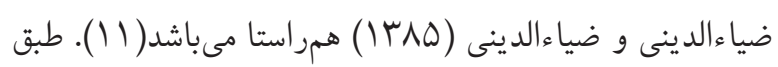
نتيجهُ مطالعهُ اخير، كمبود دانش و آكاهى در زمينهُ دخانيات از سوى مردم و نبود تو انايى لازم از سوى دستاندر كاران دستخاههاى بهداشتى در زمينهُ حساسسازى جامعهُ هدف، انگيزء افراد براى لئ مشاركت در اين طرحها كاهش مى يابد. از حيث تأثير ييش آمادگى ذهنى بر ترك سيخار، نتايج اين

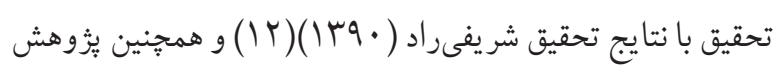

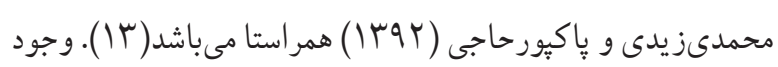
ييش آماد كى ذهنى در افراد موجب گر ايش آنها به طرحهاى جديد و يذيرش بهتر ايدهاى جديد مىشود. در يُزوهش حاضر نيز، نتايج
نتايج تحقيق حاضر در دو سطح نظرى و تجربى قابل بررسى و مقايسه با مطالعات ييشين است. از جنبهُ نظرى مىتوان كفت با توجه به اينكه بخشى از شهروندان از طرح ((تهران شهر بدون دخانيات)) اطلاعى نداشته و در حقيقت گروههاى اجتماعى مختلف دانش نسبى درخصوص اين طرح داشتند، ميزان مشاركت آنان نيز در اين طرح در حد يايين بوده است. اين يافته در راستاى نظريهُ كنش برنامهريزى شده فيشبين و آيزن (Fishbin \& Ajzen)، نظريةٌ اشاعهُ نوآورى راجرز و مدل اعتقاد بهداشتى (Hogers) مىباشد. براساس نظرئٌ آيزن و فيشبين، افراد قبل از هر اقدامى، ֶس از كسب شناخت و سنجش زواياى مختلف آن، ابتدا نسبت به آن كنش متمايل كشته و در ادامه اين كنش از آنها سَر مىزند. جنانجه نيّت و انكيزش هاى فرد نسبت به يك رفتار قوى تر باشد، احتمال ارتكاب آن رفتار نيز تقويت مىشود (^). در طرح (اتهران شهر بدون دخانيات)) نيز، با توجه به اينكه ميزان شناخت افراد نسبت به زواياى مختلف اين طرح در سطح اندك بود، ميزان مشاركت افراد نيز در حد كم ارزيابى شده است و به همين دليل ييشنهاد مىشود در گام اول و قبل از اجراى جنين طرحهايى، زمينهها و اقدامات لازم براى افزايش دانش شهروندان درخصوص طرح فراهم شود و سيّ نسبت به ييادهسازى آن اقدام شود. براساس نظرئُ راجرز نيز، يذيرش هر گونه نوآورى از سوى جامعهُ هدف بايستى براساس افزايش آكاهى آنان صورت يذيرد و تازمانيكه آكاهى افراد در زمينهُ موضوعى جديد، در سطح اندك و حداقلى باشد، نمى توان انتظار يذيرش ايدههاى جديد را داشت( (9). در اجراى طرح ((تهران شهر بدون دخانيات)) نيز در وهله نخست 
لازم است به عنوان كام اول، به اين مهم توجه نمايند تا بتوانند

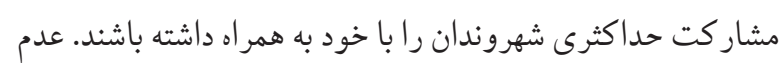

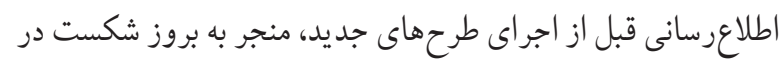

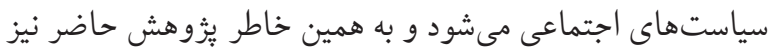

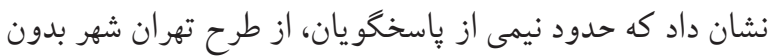

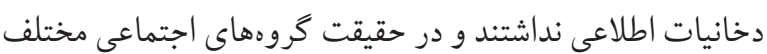

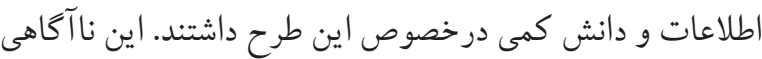

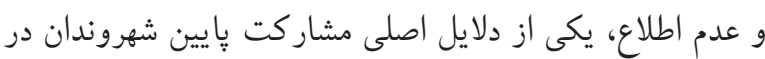
اجر اى طرح ((تهران شهر بدون دخانيات)) و كنترل دخانيات است.

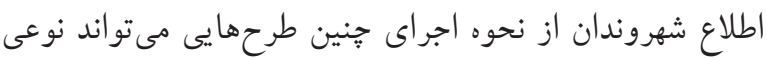

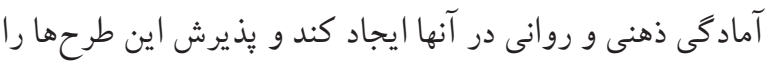

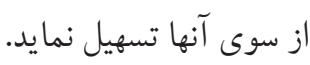

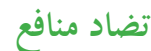
سهم تمامى نويسندگان در اين مطالعه يكسان است و هيجز گونه تضاد منافعى وجود ندارد.

\section{References}

1. Makvandi Z, Sharifi M, Barati M. Assessment of Factors Associated With Hookah Consumption Among College Students of Asad Abad City Base on The Theory of Planned Behavior (TPB) in 2015-2016. Iranian Journal of Health Education and Health Promotion. 2017;5(4):270-9. [DOI:10.30699/acadpub.ijhehp.5.4.270]

2. Bahari A, Marin S, Nikniaz L, Tabrizi JS, Sahebihagh $\mathbf{M H}$ Fakhari A, et al. Effective Programs and Interventions in Prevention and Reduction of Tobacco Use in Communities: A Review Study. Depiction of Health. 2018;9(2):134-48.

3. Panahi R, Ramezankhani A, Tavousi M, Osmani F, Niknami $S$. The relationship between low health literacy and knowledge and attitude towards the harms of smoking in dormitory students. Journal of Health Literacy. 2017;2(3):131-40. [DOI:10.22038/jhl.2017.10874]

4. Miraftab F. Public-private partnerships: The trojan horse of neoliberal development? Journal of planning education and research. 2004;24(1):89-101. [DOI:10.1177/0739456X04267173]

5. Lor PJ. The IFLA-UNESCO partnership 1947-2012. IFLAjournal. 2012;38(4):269-82. [DOI:10.1177/0340035212463138]

6. Hakim S, Chowdhury MAB, Uddin MJ. Correlates of attempting to quit smoking among adults in Bangladesh. Addictive behaviors reports. 2018;8:1-7. [DOI:10.1016/j.
نشان داد كه افر اد سيخارى، اطلاعات كمترى نسبت به طرح تهران بدون دخانيات دارند و به همين دليل مشاركت آنها در طرح كمتر از افراد غيرسيخارى بوده است.

مهمترين محدوديتهاى اين تحقيق در دو دستة كلى قابل تقسيم

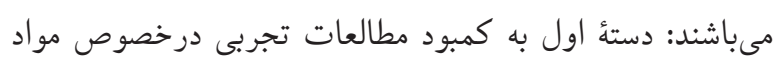

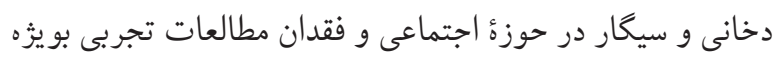

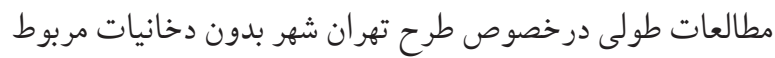
بود كه البته اين فقدان، نوعى مزيت براى تحقيق حاضر بود كهو كه آن را فتحبابى براى آغاز مطالعات بيشتر و عميقتر در اين زمينه بدل برل بردي كرده است. دسته دوم از محدوديتها، در سطح جمع آورى دادهها بود كه عدم همكارى برخى از افراد نمونه جهت تكميل يرسشنامه بو يزه در سؤالات مربوط به مصرف انواع مو اد دخانى بود كه طبيعتاً نرخ بى ياسخى را افزايش داده است.

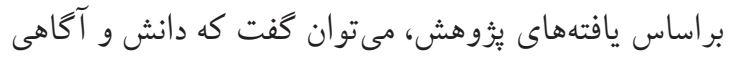
افراد، مقدمهاى براى بذيرش ايدههاى جديد و هر گونه طرح نو آورانه

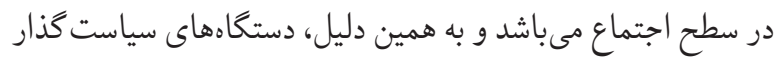

abrep.2018.04.002] [PMID] [PMCID]

7. Tucker JS, Green Jr HD, Zhou AJ, Miles JN, Shih RA, D'Amico EJ. Substance use among middle school students: Associations with self-rated and peer-nominated popularity. Journal of adolescence. 2011;34(3):5139. [DOI:10.1016/j.adolescence.2010.05.016] [PMID] [PMCID]

8. Aliakbari R, Vahedian-Shahroodi M, Abusalehi A, Jafari A, Tehrani H. A digital-based education to improve occupational health and ergonomic conditions of dentists: an application of theory of planned behavior. International Journal of Health Promotion and Education. 2019:1-14. [D Ol:10.1080/14635240.2019.1687316]

9. Dibra M. Rogers theory on diffusion of innovation-the most appropriate theoretical model in the study of factors influencing the integration of sustainability in tourism businesses. Procedia-Social and Behavioral Sciences. 2015;195:1453-62. [DOI:10.1016/j.sbspro.2015.06.443]

10. Champion VL, Skinner CS. The health belief model. Health behavior and health education: Theory, research, and practice. 2008;4:45-65.

11. Ziaadini h, Ziaadini r. The prevalence of tobacco use and dependency and its relation to some demographic factors in people aged 12 and over in rural sample. Journal 
of Fundamentals of Mental Health. 2006;8(30):17-22. [DOI:10.22038/jfmh.2006.1815]

12. Sharifirad Gh. Smoking behavior among male student's bases on trans-theoretical model. Journal of Fundamentals of Mental Health. 2011;13(52):95-386. [DOI:10.22038/ jfmh.2011.926]
13. Mohammadizeidi E, Pakpour A. Effectiveness of an educational intervention based on theory of planned behavior to reduce intentions to smoke among secondary school students. Journal of Research and Health. 2013;3(4):504-13. 